\title{
Can Pay-as-you-go System Trigger Payment Crisis in China?
}

\author{
Han SUN ${ }^{1, a}$, Ning NING ${ }^{2, b}$, Wu-Jun SUN ${ }^{3, c, *}$ \\ ${ }^{1}$ School of business, Nanjing University, P R China \\ ${ }^{2}$ School of business, Nanjing University, P R China \\ ${ }^{3}$ School of business, Nanjing University, P R China

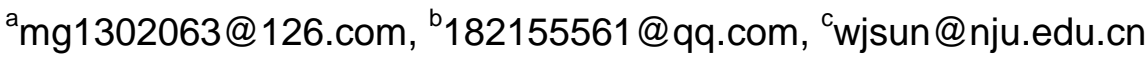 \\ ${ }^{*}$ Corresponding author
}

Keywords: Population aging, Endogenous growth, PAYG, Pension tax rate, Savings rate.

\begin{abstract}
China has implemented the part funded system of pension project management, but the personal part of pension account has been empty running since the reform, 1997. The problem cannot be solved in short term, and the old-age pension system still be supported by the pay-as-you-go (PAYG in short) system account. So the research of PAYG system is significant. Different from these former papers, this paper takes the perspective of the entire economies, constructs an endogenous growth model, tries to find the path of how population aging affects the pension tax rate and discusses whether the PAYG system can result in a payment crisis. Conclusions show that in a short time, the multiple of unit worker's output is a single factor to determine the pension tax rate, so the PAYG system would not have a payment crisis in short term; in a long time, population aging affects pension tax rate under the influence of savings rate. The aggravation of population aging causes a decline in savings rate, and then the pension tax rate increases. There is a positive correlation between the pension tax rate and the estate transfer rate, education investment rate. And also, the pension tax rate has an inhibitory effect on the decreasing of savings rate. In that way, the rising extent of pension tax rate would be reduced. Pension tax rate has the function of automatic stabilizers and long-term aging of the population does not necessarily lead to the occurrence of PAYG system payments crisis.
\end{abstract}

\section{Introduction}

Currently, there are three major worldwide pension collection models: PAYG, fully funded and part funded. The United States, Britain and Japan all adopt PAYG pension system model, in which expenditure is determined by revenue and there is no danger of inflation. This model has strong function of redistribution between inter-generational and intra-generational high and low income groups, with strong social freemasons. However, people began to consider the pension payment capacity 4 and the burden of young people, with the economic development and the advent of an aging population. Some countries such as Chile that previously implement PAYG system began to try to raise pensions by accumulation fund system, in which payment and treatment are related. Although this system can resist population aging, it has great devaluation risk.

\footnotetext{
${ }^{1}$ School of business, Nanjing University, P R China

${ }^{\text {a }}$ Email address: mg1302063@126.com

${ }^{2}$ School of business, Nanjing University, P R China

${ }^{\mathrm{b}}$ Email address:182155561@qq.com

${ }^{3}$ School of business, Nanjing University, P R China

${ }^{c}$ Email address: wjsun@nju.edu.cn

*Corresponding author: Sun wujun, Associate professor, department of finance \& insurance.

${ }^{4}$ China's endowment insurance system is the partial fund system. The article explains the individual accounts of fully funded as pension insurance fund, pension tax rate as insurance fund contribution rate; Pooling accounts in PAYG are called Old-age insurance system in our country as pension insurance, and the contribution rate of pooling accounts is called pension tax rate for short; To avoid confusion, these two accounts are collectively known as annuity, the sum of the two contribution rates is called pension tax rate.
} 
State council of China determines the changes in the China basic pension insurance for a combination of social pooling and personal accounts in 1997, in other words, the pension project management is the combination of PAYG and fully funded, called part funded. This project management is characterized by that the initial pension tax rate is higher but financing quickly, pension tax rate remained relatively stable in the longer term. Not only embody social equity and welfare, but also accumulate fund, as a safeguard against payments crisis when the peak of aging population comes. At the beginning of the transition, however, retired old men, as well as those who work but haven't retired enjoy pension treatment after the reform without the individual accumulation accounts. As a result, a huge amount of implicit pension debt has formed, and transition costs of structural reform caused the insufficiency of social security pension and empty running of personal account. The Report of Chinese Pension Development 2011 compiled by the Chinese Academy of Social Sciences shows that transfer payments to the pension insurance are made by all levels of government with an increasingly scale, since 1997, totaled 1.2526 trillion to 2011 , but still not be able to fill the 8 trillions pension empty. In June, 2012, MHRSS said they would timely put forward the policy recommendation that elastically rise the age of basic pensioners. Pan Jintang, the deputy director of social security research center of China, who comes from RUC, said in an interview5: "Raising the retirement age can make an increase in the pension of 4 billion per year and reduce expenses of 16 billion." However, once retirement is postponed, some questions such as the time and cost of policy implementation etc. emerge, the major of which is young people can't get into the corresponding post while the aged haven't retired. As a result, serious employment problems would be caused.

As the trend of population aging is aggravating, there is possibility that PAYG system would trigger payment crisis. In view of China's current pension project management, as well as personal accounts hole problem cannot be solved in a short span of time, the PAYG part is now the fundamental of China's social pension insurance system. The research on whether the PAYG system would trigger payment crisis means a lot, with great significance both in theory and practice.

\section{Literature Review}

Academic research on old-age insurance system has been for a long time in the academic circles. Samuelson (1958) [1] used pure savings model to prove that in the circumstance of lack of technological progress and fixed work time, the pension yield only depends on the population growth rate. Then, Henry (1966) [2] demonstrated that the pension yield depends on the growth rate of population, as well as that of labor productivity, on the base of Overlapping-generations model. In 1974, Feldstein [3] proposed the "crowding out" of the pension insurance, two opposite directions of which, wealth substitution effect" and "induced retirement effect", affect personal saving behavior. The influence of national pension tax rate to economy lies on the relative Impact of above two effects. Besides, the U.S. PAYG system leads to a decline by $30 \%$ to $50 \%$ of private savings, which is not conducive to economic growth. And Barro (1974) [4] said PAYG has no effect on present consumption, aggregate demand and savings by means of intergenerational diversion, in other word, economic growth is neutral, on the basis of Overlapping-generations model, altruism included.

Institutional diversification must lead to institutional choice. Compared with fully funded, the question whether PAYG is better or not had already been solved by Verbon (1993) [5] through Pareto optimality theory in 1988. He concluded that once PAYG is selected, exit cannot occur without harming the benefit of one generation. However, if we choose to transfer from fully funded to PAYG, no generations will suffer the loss, and at least one generation will benefit from that. Different from Verbon, Barr (1993) [6] debated that there is no essential difference between PAYG and fully funded in response to the question of demographic changes. Breyer(2001) [7] carried forward the research of Verbon, thought that Verbon's conclusion could not only be applied to open economy, but also be applied to closed economy. Yang (2008) [8] analyzed the differences of effect between PAYG and

\footnotetext{
${ }^{5}$ The news was released in tencent financial on June 8, 2012, http://finance.qq.com/a/20120608/000631.htm
} 
fully funded to physical capital accumulation and investment in human capital, drew the conclusion: the two systems have no absolute advantage than each other, during pension reform, the path dependence of system, the reform cost and some other comprehensive supporting measures should be took into account. Ediev (2013) [9] put forward that PAYG is even more popular than fully funded with more and more longevous people contained in population structure, because a longer retirement than the present will make retirees require more pension, the cost of offering pension to the current retirees will be less than that of accumulating pension fund.

Study on PAYG mainly concentrates on two aspects: on the one hand, whether payment crisis will occur with population aging, on the other hand, the influence of pension tax rate to each factor in economy and economic development. In 1997, Lans (1997) [10] found in the study of OECD countries pension insurance system that in one aging society, the PAYG system would trigger the payment crisis, while the fully funded system wouldn't. Gao (2002) [11] used pension tax rate actuarial models under PAYG to analyze: population aging of this century is approaching, the continue of PATG will trigger payment crisis. Cheng (2005) [12] gave the quantitative criterion of whether the PAYG system occurs payment crisis. He explained that as long as growth rate of output per capita is no less than 3\%, PAYG will not trigger payment crisis. Fanti (2010) [13] analyzed how the change of fertility affects pension tax rate in a long time on the base of Overlapping-generations model, and results showed that the decline of fertility does not necessarily cause PAYG failure. Then, in regard to the influence of pension tax rate to each factor in economy and economic development, Balestrino (2002) [14] pointed out: PAYG system will cause the externalities problem of raising children, but also reduce the opportunity cost of raising children, fertility rates vary depending on the relative size of the two effects. Siew (2009) [15] and others hold: as long as the parents' tastes to their children's quality are not particularly weak, PAYG system can reduce the birth rate and increase the per capita level of human capital, and thus conducive to economic growth, and scaling up PAYG pension tax rate would improve social welfare by reduce fertility and raise capital intensity, until reaching an optimal tax rate. Wang (2010) [16] used relevant panel data from 2002 to 2007 of 30 provinces in China to investigate the impact of PAYG pension insurance on savings. The research show that PAYG system has increasingly "crowding out" effect on savings, the effect to consumption of pension wealth is less than that of income. The article also puts forward that increasing pension wealth by means of expanding wealth endowment insurance coverage can solve the problem of high savings rate and promote the economic development. Fanti (2012) [17] studied the steady-state and dynamic output of household internal transfer of pension and PAYG, through the general equilibrium overlapping-generations model, preference for children included. Results show that converting from household internal transfer of pension to PAYG will increase unit labor output, and PAYG can significantly reduce the instability of the economic cycle rather than household internal transfer of pension.

Recently, domestic scholars pay a lot of attention to the endowment insurance system in China and its special problems. Sun (2001) [18] thought that if the problem of transition costs hasn't been solved, individual account is difficult to convert from the current empty account to real account, the existing system is essentially still PAYG system. Li (2010) [19] used overlapping generation model to verify the income after transition in the context of taking the implicit debt brought by endowment insurance system in China into consideration. Result showed that the transition from PAYG to fully funded can't generate any revenues on the premise of not affecting intergenerational distribution, these two systems are equivalent; However, in the case that intergenerational redistribution is allowed, transition is conducive to the improvement of the whole social benefits. Yin (2012) [20] built fund balance model from the perspective of the gross, estimated the income and expenditure of fundamental annuities in China in the coming 90 years under the current payment regulations, and investigated whether the current basic pension plan can reply to the impact of the population age structure changes. The study found the current retirement age and pension insurance policy in China is not enough to achieve long-term financial balance of the basic pension, unifying the retirement age to 60 is helpful for the solvency of protection scheme; In the preliminary, fundamental pension is in the 
stage of revenue exceeding expenditure, if the surplus money can be invested to obtain a stable return, the later payment pressure can be relieved to realize the balance of basic pension payment.

As previously stated, there isn't a uniform consensus on the choice of pension system, such as Verbon (1993), Friedrich (2001) tend to fully funded, Ediev (2013) thinks that workers prefer to PAYG, while Barr (1993) and Yang (2008) think there is no difference between these two. Opinions on whether PAYG will trigger payment crisis are inconsistent. Lans (1997) and Gao (2002) think PAYG will trigger payment crisis, while Cheng (2005) thinks that as long as growth rate of output per capita is no less than 3\%, PAYG will not trigger payment crisis. Research methods on the relationship between PAYG pension tax rate and each factor in economy are relatively uniform, most of which are overlapping generation models, but the assumption about the preferences to children is not suitable for China, as the fertility rate in China is not decided by individual preference, because of the basic national policy of family planning. It's not hard to see, studies on the PAYG are plentiful but points of view are different. China's pension project management is mainly supported by the PAYG part. This paper focuses on PAYG pension insurance, studies pension tax rate based on endogenous economic growth, and different from the former papers set model on the perspective of family, this paper set an overlapping generation model from the view of whole economy, considering the downward altruism exist, study the path of population aging affects the pension tax rate, simplify the numerous criterion of whether the PAYG system occurs payment crisis to a single condition about units laborers output, and analyzes relationship between the pension tax rate and the savings rate, property transfer rate, offspring education investment rate.

\section{Model}

Define $U(\bullet)$ as the total utility function of the entire infinite periods economies with a large number of indifference rational individuals exist in the economies. Every single period, the utility of the economies equals to the logarithmic sum of everyone's consumption function. The utility of the entire infinite periods economies denoted by the discounting sum of $t$ periods utility, $t \in[0,+\infty)$. The assumptions above wouldn't violate the basic assumptions of economics, have no effect to the relationship of the independent variable and dependent variable and can make the processing of the model easier. Divide the population into three groups, the young, the middle-age, and the old. The young have access to education and embody human capital subsidized by parents, they have no income and do not make any decision. The middle work and get wages, pay pension insurance and other taxes, transfer property between parents, raise children, make decisions on savings independently. The old retired, live on pension and savings, decide the allocation between the amount of bequests to children and their own consumption. Assume 24 years per period, the youth are 1-24 years old, the middle-age are 25-48 years old and the old are 49-72 years old, this assumption in line with China's labor structure and the average life expectancy, moreover single period's length close to the Kuznets cycle. Denote the mass of the youth, the middle-age, the old living in period $t$ as $N_{Y, t}, N_{M, t}, N_{O, t}$, use $C_{M, t}, C_{\mathrm{O}, t}$ as the consumption of the representative individual from the middle-age and the old, define $E_{t}$ as the education investment to one's single child of a representative middle-age whom living in period $t$. Under the discounting rate $\alpha(0<\alpha<1)$, the total utility of entire economies:

$$
U=\sum_{t=0}^{\infty} \alpha^{t}\left(N_{O, t} \ln C_{O, t}+N_{\mathrm{M}, t} \ln C_{M, t}+N_{Y, t} \ln E_{t}\right)
$$

The youth in period $t$ become the middle-age in period $t+1$ and start working, the middle-age in period $t$ become the old in period $t+1$, retired and get pension, denote the population replacement ratio as $P_{t}=N_{Y, t} / N_{M, t}=N_{M, t+1} / N_{\mathrm{O}, t+1}$. A single representative middle-age's consumption equals to the income subtract saving and investment in educating children. Incomes are constituted by the after-tax wages and the property transfer from parents, wages equal to $W_{t} H_{t}$ where $W_{t}$ is the wage rate per unit 
of effective labor and $H_{t}$ is one's human capital in period $t$, the $H_{t}=H\left(E_{t-1}\right)$ related to the education lever in one's youth period. Use $\tau_{t} \in(0,1)$ as the pension tax rate and use $\bar{\tau} \in(0,1)$ as any other tax rate, both of them are exogenous variables, whereby the bar above a variable indicates its average level in the economy. A middle-age individual receives an amount of $B_{t}>0$ from parents, this is a personal property transfer which is different from the government transfer payments, government can levy a ratio $\eta$ of the $B_{t}$ property transfer tax, generally $\eta=0$ when parents are alive and $B_{t}$ can be regarded as simple transfer of property, $0 \leq \eta \leq 1$ when parents are passed and $B_{t}$ can be regarded as bequest. $N_{M, t}$ middle-age individuals can get the amount of property of $N_{O, t} B_{t}(1-\eta)$, so single representative middle-age individual can get the amount of property transfer of $(1-\eta) B_{t} / P_{t-1}$. Similarly, $N_{M, t}$ middle-age individuals raise $N_{Y, t}$ youth individuals, the single representative middle-age individuals' investment to children education is $P_{t} E_{t}$. Define $S_{t}$ as saving, $R_{t}$ as interest rate, the representative old individual consumes part of his income, leaves the rest to his or her children. The consumption of the middle-age and the old individual can be written as:

$$
\begin{aligned}
& C_{M, t}=\frac{1}{P_{t-1}}(1-\eta) B_{t}+\left(1-\tau_{t}-\bar{\tau}\right) W_{t} H_{t}-S_{t}-P_{t} E_{t} \\
& C_{O, t}=\tau_{t} P_{t-1} W_{t} H_{t}+S_{t-1} R_{t}-B_{t}
\end{aligned}
$$

Use C-D function to interpret total production, then total production of period $t$ can be written as:

$$
Y_{t}=D K_{t}^{\theta}\left(N_{M, t} H_{t}\right)^{1-\theta} \text { with } D>0
$$

factors are paid by their marginal products, the wage rate per unit of effective labor and the interest rate are then given by:

$$
\begin{aligned}
& W_{t}^{*}=(1-\theta) D \mu^{\theta} \\
& R_{t}^{*}=\theta D \mu^{(\theta-1)}
\end{aligned}
$$

Where $\mu=K_{t} /\left(N_{M, t} H_{t}\right)$ is the ratio of physical capital to effective labor. The physical market clears when:

$$
K_{t+1}=N_{M, t} S_{t}
$$

\section{Model analysis}

This part we will solve the dynamic economies model. Substitute Eq. (2) and (3) into Eq. (1), and maximize Eq. (1), then we obtain:

$$
\begin{gathered}
\max _{B_{t}, S_{t}, F_{t}} \sum_{t=0}^{\infty} \alpha^{t}\left\{N_{M, t} \ln \left[\frac{1}{P_{t-1}}(1-\eta) B_{t}+\left(1-\tau_{t}-\bar{\tau}\right) W_{t} H_{t}-S_{t}-P_{t} E_{t}\right]+N_{O, t} \ln \left[\tau_{t} P_{t-1} W_{t} H_{t}+S_{t-1} R_{t}-B_{t}\right]\right. \\
\left.+N_{Y, t} \ln E_{t}\right\}
\end{gathered}
$$

The first-order conditions with respective to $B_{t}, S_{t}, P_{t}$ are given as follows: 


$$
\begin{aligned}
& \frac{1-\eta}{C_{M, t}}=\frac{1}{C_{O, t}} \\
& \frac{1}{C_{M, t}}=\frac{\alpha R_{t+1}}{C_{O, t+1}} \\
& \frac{\alpha \tau_{t+1} W_{t+1} H_{t+1}}{C_{O, t+1}}=\frac{\alpha(1-\eta) B_{t}}{C_{M, t+1} P_{t}}+\frac{E_{t}}{C_{M, t}}
\end{aligned}
$$

Define $y_{t}=Y_{t} / N_{M, t}$ as output per worker, letting the fraction of output per worker spent on item be $x=X_{t} / y_{t} . X_{t}=B_{t}, S_{t}, E_{t}$ can be a time-invariant lower-case variable in that way, we transform the variable in the conditions into their relative ratios to output per worker, there are $b>0, s>0, e>0$. Denote property transfer rate, saving rate, education investment rate, then Eq. (8) to (9) can be written as:

$$
\begin{aligned}
& \frac{1-\eta}{C_{M}}=\frac{1}{C_{O}} \\
& \frac{1}{C_{M}}=\frac{\alpha P_{t}}{s C_{O}} \\
& \frac{\alpha(1-\theta) \tau_{t+1} y_{t+1}}{C_{O}}=\frac{\alpha b(1-\eta) \mathrm{y}_{t}}{C_{M} P_{t}}+\frac{e y_{t+1}}{C_{M}}
\end{aligned}
$$

organize Eq. (11) and (12) we get:

$$
s=P_{t} \alpha(1-\eta)
$$

differentiate $s$ with respect to $P_{t}$ and solve elasticity:

$$
\begin{aligned}
& \frac{d s}{d P_{t}}=\alpha(1-\eta)>0 \\
& E=\frac{d s}{d P_{t}} \mathrm{~g} \frac{P_{t}}{s}=1
\end{aligned}
$$

Usually the international standard of the aging of the population is: the population over the age of 60 accounted for $10 \%$ of total population, the population over the age of 65 accounted for $7 \%$ of total population. This paper assumes that the 49-72 year-old population is old, but its essential character is retired and gets pension payment, the same with that of the old in the population aging standard, so we can approximate population replacement ratio to characterize the population aging level: 


$$
\text { population aging level }=\frac{1}{1+P_{t-1}+P_{t-1} P_{t}} 6
$$

So, the process of aging aggravated is also a process of population replacement ratio decreasing. Since China implemented the "birth control" as a basic national policy in 1982, the fertility rate has decreased from 2.6 to 1.6, tending to go down according to World Bank statistics. It goes without saying that reductions in fertility lead to youth diminishing, and population replacement ratio $P_{t}$ continued to decrease, aging problem becomes more and more serious.

Conclution1: Savings rate decreases as population aging gets more serious, and savings rate and population replacement ratio is positively correlated with the elasticity of 1 .

The process of population aging aggravated is also a process of population replacement ratio decreasing. The derivative of savings rate with respect to population replacement ratio is less than zero, so savings rate decreases as population aging gets more serious, for every $1 \%$ decrease in population replacement ratio, the savings rate decreased by $1 \%$. And, in the process of aging, the population replacement ratio is declining, leading to lower savings rate. As is known to all, China is a typical country of high savings rate, compared to the other countries of low savings rate, China's exposure to the economic impact is smaller in the process of aging.

Substitute Eq. (11), (12) and (14) into Eq. (13), after organize:

$$
\tau_{t}=\frac{\alpha b(1-\eta) y_{t-1}}{s(1-\theta) y_{t}}+\frac{e}{\alpha(1-\eta)(1-\theta)}
$$

Define the multiplier of output per laborer $J_{t}=\frac{y_{t}}{y_{t-1}}>0$, and then Eq. (18) can be written as:

$$
\tau_{t}=\frac{\alpha b(1-\eta)}{s(1-\theta) J_{t}}+\frac{e}{\alpha(1-\eta)(1-\theta)}
$$

Differentiate Eq. (19) respect to s:

$$
\frac{d \tau_{t}}{d s}=-\frac{\alpha b(1-\eta)}{s^{2}(1-\theta) J_{t}}<0
$$

Conclution2: The current pension tax rate is decided by the current multiplier of output per laborer, affected by the savings rate, associated with the property transfer rate and the education investment rate.

In short term, property transfer rate, savings rate and the education investment rate are constant, pension tax rate changes by the sole determinant of the multiplier of output per laborer. In long term, savings rates decrease if the aging problem get worse, push the pension tax rates rising; savings rate would getting steady if aging process has stabilized, savings rate changes have no significant effect on the changes of pension insurance tax rate, pension tax rate still decided by the multiplier of output per labor.

Since $\tau_{t}$ Solved through social utility-maximizing equilibrium, if the pension tax rates rise over time, the workers will eventually unable to sustain the insurance tax one day, resulting in the payment of the

$$
\begin{aligned}
{ }^{6} \text { population aging level } & =\frac{N_{O, t}}{N_{Y, t}+N_{M, t}+N_{O, t}}=\frac{N_{O, t} / N_{O, t}}{N_{Y, t} / N_{O, t}+N_{M, t} / N_{O, t}+N_{O, t} / N_{O, t}}=\frac{1}{\frac{N_{Y, t}}{N_{M, t}} \mathrm{~g} \frac{N_{M, t}}{N_{O, t}}+P_{t-1}+1} \\
& =\frac{1}{1+P_{t-1}+P_{t-1} P_{t}}, \text { where } \frac{N_{M, t}}{N_{O, t}}=\frac{N_{Y, t-1}}{N_{M, t-1}} .
\end{aligned}
$$


pension insurance crisis. On the other hand, if $\tau_{t}$ doesn't rise over time, there is no problem of payment crisis as expenditure beyond revenue. So the discrimination of whether PAYG system would trigger a payment crisis can be obtained by judging whether $\tau_{t}$ increases with time, that is whether $\frac{d J_{t}}{d t}$ is positive or negative.

To investigate the decisive factors related to the symbol of $\frac{d J_{t}}{d t}$, differentiate Eq. (19) respect to $t$ :

$$
\frac{d \tau_{t}}{d t}=-\frac{\alpha b(1-\eta)}{s^{2}(1-\theta)^{2} J_{t}^{2}}\left(\frac{d J_{t}}{d t}\right)
$$

Criterion: when $\frac{d J_{t}}{d t}<0$ or can be interpreted as $\frac{d \tau_{t}}{d_{t}}=-\frac{\alpha b(1-\eta)}{s^{2}(1-\theta)^{2} J_{t}^{2}}\left(\frac{d J_{t}}{d t}\right)>0$, the PAYG system would occur payment crisis.

Combined with the definition of multiplier of output per labor: $J_{t}=\frac{y_{t}}{y_{t-1}}$, the symbol of $\frac{d J_{t}}{d t}$ is decided by the variation trend of output per labor. Select the data of GDP and total number of the employed population ${ }^{7}$, get the annual output per laborer ${ }^{8}$ and annual multiplier of output per labor ${ }^{9}$ after simple treatment, then we can draw the "Figure of Output per Labor" and "Figure of Multiplier of Output per Labor". In Figure 1, the annual output per laborer growing exponentially and has the trend to growth continually. In Figure 2, the multiplier of output per labor growing around the trend line fluctuating except two special year of 1990 and 1994, this paper assuming that every period has 24 years, so $\frac{d J_{t}}{d t}$ always bigger than 0 by 2011 whenever we start to count between 1979 to 1981 . Moreover, $\frac{d J_{t}}{d t}>0$ in short term according to the trend shown in Figure 1.

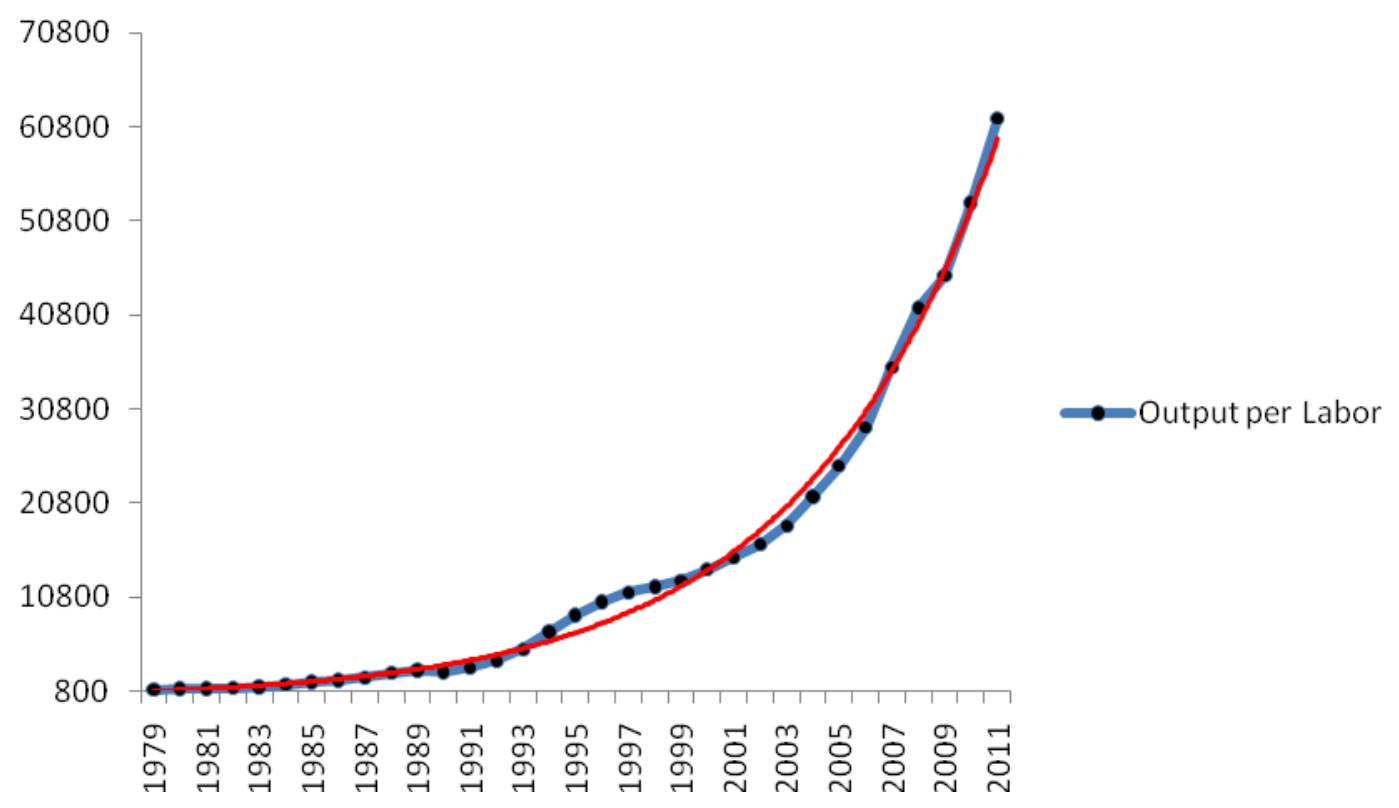

Figure 1: Output per Labor, 1979-2011 $1^{10}$

\footnotetext{
${ }^{7}$ Data come from the China Statistical Yearbook.

${ }^{8}$ Annual output per laborer=annual GDP/ total number of the employed population.

${ }^{9}$ Annual multiplier of output per labor= annual output per laborer of current year/annual output per laborer of last year

${ }^{10}$ The solid black point indicates data of current year, connected by heavy blue line, the light red one is the exponential trend line.
} 


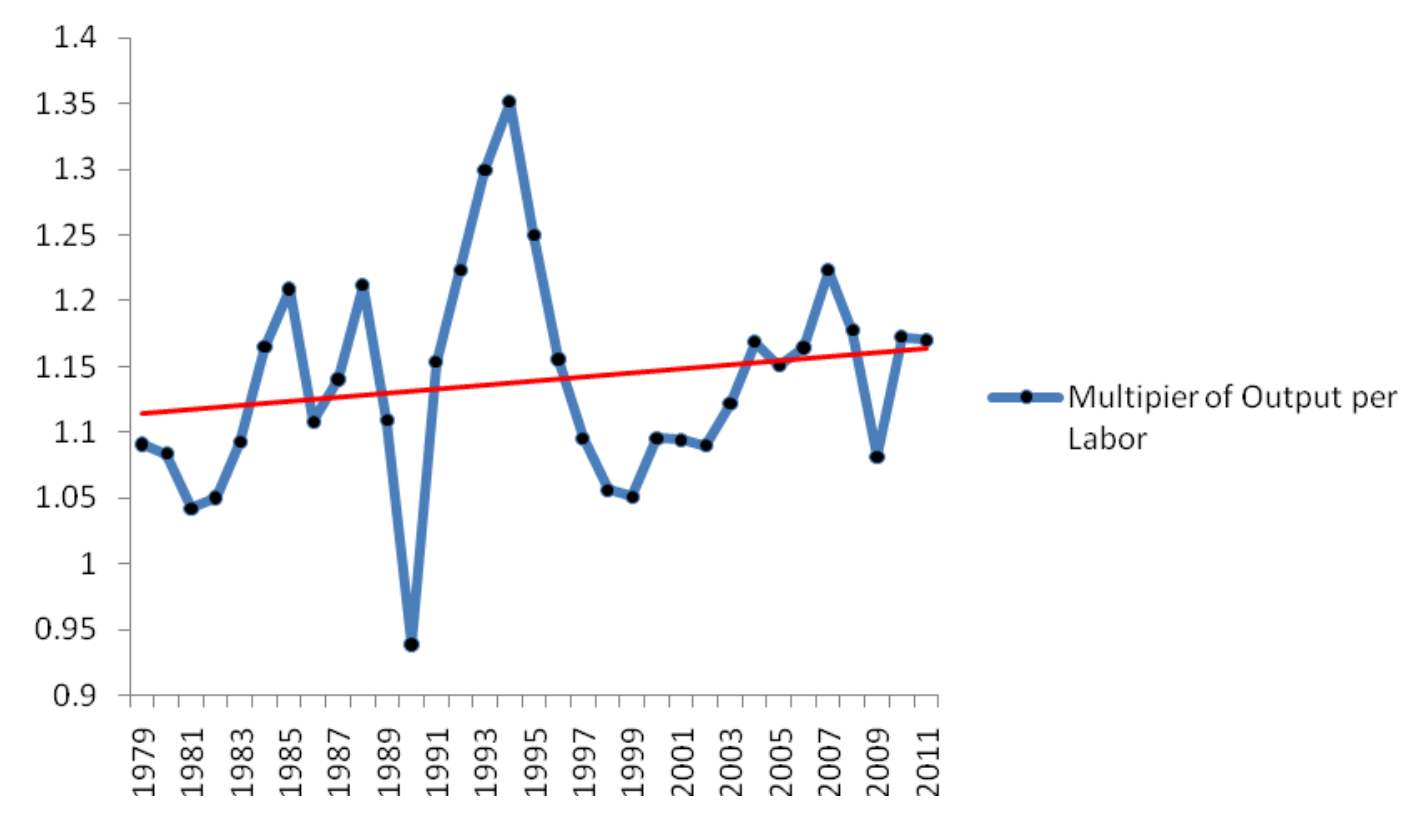

Figure 2: Multiplier of Output per Labor, 1979-2011 11

Conclution3: In short term, the PAGY system wouldn't trigger the payment crisis in China. In long term, the PAGY system wouldn't trigger the payment crisis either if the annual output per labor doesn't decline.

In the short term, output per labor grows exponentially, multiplier of output per labor has a linear trend line tilting to the top right, that is to say $\frac{d J_{t}}{d t}>0$, known from the criterion $\frac{d \tau_{t}}{d t}<0$, the optimal pension tax rate will not rise over time, so PAYG will not trigger payment crisis in a short time. Similarly, if output per labor doesn't decrease in a long term, $\frac{d \tau_{t}}{d t}$ is less than zero can be guaranteed, PAYG will not trigger payment crisis.

Differentiate Eq. (19) respect to b and e respectively:

$$
\begin{aligned}
& \frac{d \tau_{t}}{d b}=\frac{\alpha(1-\eta)}{s(1-\theta) J_{t}}>0 \\
& \frac{d \tau_{t}}{d e}=\frac{1}{\alpha(1-\eta)(1-\theta)}>0
\end{aligned}
$$

Conclution4: Pension tax rate has a positive impact on the education investment rate and property transfer rate.

Property transfer rate and the education investment rate will rise as pension tax rates increase. On one hand, the more the pension tax rate , the more available sources of funding for the old, the more property can be transferred to the offspring, the less disposable income for the middle-age, in considering the burden of the offspring, the old transfer more of property to the middle-aged. On the other hand, once the pension tax rate increases, people expect it would improve more, offspring's burden would increase in future too, so parents investment more in educating children, in order to make them have more human capital when they start working, the ability to obtain a higher income, so the middle-age increase the education investment for the youth. Conversely the anti-is.

Summarize the conclusion1 to conclusion4, with the advent of the problem of population aging, the

\footnotetext{
${ }^{11}$ The solid black point indicates data of current year, connected by heavy blue line, the light red one is the linear trend line.
} 
savings rate will be reduced, thereby driving the pension tax rate up. Once the pension tax rate increase, on the one hand the property transfer rate increases, which can restrain the decrease of disposable income, and then constrain the dropping of current savings rate; on the other hand the education investment rate for the current middle-age increases, which can make the human capital increase next period, so the offspring's income and output per labor increase, can also constrain the dropping of savings rate. Thus, drive the pension tax rate down in the current and next periods, lower the magnitude of the rise in pension tax rate. Conversely the anti-is.

Conclution5: The pension tax rate has the function of automatic stabilizers, population aging doesn't necessarily lead to PAYG payments crisis.

Pension tax rate rises sharply as savings rate decreases, because of population aging. The increase of pension tax rate generates counter-acting force to itself by influencing property transfer rate, inhibiting pension tax rate to rise in next period by influencing the education investment rate, avoiding violent fluctuate and endless rising. So population aging doesn't necessarily lead to PAYG payments crisis.

\section{Conclusion}

This paper takes the perspective on the entire economies, builds a dynamic model with endogenous growth, maximizes the utility of entire economies, and finds the path of how population aging affect the pension tax rate and the single criterion for whether the PAYG will trigger payment crisis. Inspecting the effects population aging have on PAYG payment ability by analyzing the relationship between pension tax rate and savings rate, property transfer rate, education investment rate. Conclusions can be listed as follows: 1、Savings rate and population replacement ratio is positively correlated, for every $1 \%$ increase in population replacement ratio, the savings rate increased by $1 \%$. And, in the process of aging, the population replacement ratio is declining, leading to a lower savings rate. The current pension tax rate is decided by the current multiplier of output per laborer, affected by the savings rate, associated with the property transfer rate and the education investment rate. On the one hand, the more the pension tax rate, the more available sources of funding for the old, the more property can be transferred to the offspring, the less disposable income for the middle-age, in considering the burden of the offspring, the old transfer more of property to the middle-aged. On the other hand, once the pension tax rate increase, people expect it would improve more, offspring's burden would increase in future too, so parents investment more in education children, in order to make them have more human capital when they start working, the ability to obtain a more income, so the middle-age increase the education investment for the youth. 2、In short term, property transfer rate, savings rate and the education investment rate are constants, pension tax rate changes by the sole determinant of the multiplier of output per laborer, so the PAGY system wouldn't trigger the payment crisis in China. In long term, savings rate decreases if the aging problem gets worse, push the pension tax rates rising, on the one hand the property transfer rate increase which can restrain the decrease of disposable income, and then constrain the dropping of current saving rate; on the other hand the education investment rate for the current middle-age increase what can make the human capital increase next period, so the offspring's income and output per labor increase, can also constrain the dropping of saving rate. Thus, drive the pension tax rate down in the current and next periods, lower the magnitude of the rise in pension tax rate, so the pension tax rate has the function of automatic stabilizers. Savings rate would get steady if aging process has stabilized, savings rate changes have no significant effect on the changes of pension insurance tax rate, which is still decided by the multiplier of output per labor.

For the arrival of an aging population flood, the PAGY is not a helpless wreck what would trigger crisis at any time; on the contrary, the PAYG is a reliable dam in view of China's current economic development situation and trend of short-term future. In the long term, the increase of pension tax rate contribute to the accumulation of human capital, is conducive to the benign economic development. 


\section{Acknowledgements}

The authors thank the anonymous referee for his/her helpful comments. This work is supported by The National Social Science Fund of China (No.08AJY029) and PAPD of Jiangsu Province.

\section{References}

[1]Samuelson P A. An axact consumption-loan model of interest with or without the social contrivance of money [J]. Journal of Political Economy, LXVI, 1958, 66:467-482.

[2]Aaron H. The social insurance paradox [J]. The Canadian Journal of Economics and Political Science/Revue canadienne d'Economique et de Science politique, 1966, 32(3): 371-374.

[3]Martin Feldstein. Social Security, Induced Retirement, and Aggregate Capital Accumulation [J]. Journal of Political Economy, 1974, 82(5):905-926.

[4] Barro,Robert . Are Government Bonds Net Wealth? [J]. Journal of Political Economy, 1974, 82(6):1905-1117.

[5]Harrie Verbon. The Evolution of Public Pension Schemes [M]. London: Springer-Verlag,1988.

[6]Barr N A. The economics of the welfare state [M]. Stanford university press, 1993.

[7]Friedrich Breyer,Klaus Stolte. Demographic change, endogenous labor supply and the political feasibility of pension reform [J]. Population Economics, 2001, 14:409-424

[8]Jiguang Yang, Hailong Liu, Youchuan Xu. China's Social Security Programs Based on Endogenous Economic Growth Model [J]. Journal of Shanghai Jiao Tong University, 2008, 42(11): 1806-1809. (In Chinese)

[9]Ediev D M. Why increasing longevity may favour a PAYG pension system over a funded

System [J]. Population studies, 2013 (ahead-of-print): 1-16.

[10]Lans Bovenberg,Anja van der Linden . Pension Policies and the Aging Society [J]. Organization for Economic Cooperation and Development, 1997, 205:10-14.

[11]Gao Jianwei,Qiu Wanhua. The Model of Contributing Rate under Pay-As-You-Go System and Partially Accumulated System [J]. Chinese Journal of Management Science, 2002, 4: 82-85. (In Chinese)

[12] Yonghong C. Quantifying analysis on the relationship between PAYG system and population aging [J]. Economic Research Journal, 2005, 3:57-68. (In Chinese)

[13]Fanti L, Gori L. Economic growth and stability with public PAYG pensions and private intra-family old-age insurance[J]. 2010, MPRA Paper 20727, University Library of Munich, Germany.

[14]Balestrino A, Cigno A, Pettini A. Endogenous fertility and the design of family taxation [J]. International Tax and Public Finance, 2002, 9(2): 175-193.

[15]Siew Ling Yew,Jie Zhang. Optimal social security in a dynastic model with human capital externalities, fertility and endogenous growth [J]. Journal of Public Economics, 2009, 93:605-619.

[16]Yang Shi, Manchang Wang. The Effect of PAYG Pension Insurance on Savings [J]. Quantitative \& Technical Economics Research, 2010 (3): 96-106. (In Chinese)

[17]Fanti L, Gori L. Fertility and PAYG pensions in the overlapping generations model [J]. Journal of Population Economics, 2012, 25(3): 955-961.

[18]Sun Qixiang. "Empty accounts" and transition costs [J]. Economic Research, 2001, 5. (In Chinese) 
[19] Li Shiyu. Returns Analysis From PAYGO System to Fund Accumulation System: Theoretical Analysis and Simulation of Overlapping Generations Model with Implicit Debt[J]. FINANCE, 2010, 8: 012. (In Chinese)

[20]Jun Yin, Rong Huang. Population aging, retirement and long-term solvency of the basic Pension[J]. REFORM AND DEVELOPMENT, 2012 (4): 73-76. (In Chinese) 